\title{
PEMANFAATAN KULIT SKROTOM SAPI SEBAGAI BAHAN BAKU INDUSTRI BARANG KULIT
}

\author{
Muchtar Lutfie ${ }^{1)}$, Widhiati ${ }^{1)}$
}

\begin{abstract}
INTISARI
Penelitian ini bertujuan untuk memanfaatkan kulit skrotom sapi sebagai bahan baku industri barang kulit. Empat puluh lima buah kulit skrotom sapi disamak menjadi kulit kras dengan bahan penyamak mineral $6 \% ; 8 \%$ dan $10 \%$, penyamak nabati $15 \% ; 20 \%$ dan $25 \%$, penyamak sintetis $15 \% ; 20 \%$ dan $25 \%$. Hasil uji fisika menunjukkan bahwa kulit skrotom sapi bisa dimanfaatkan menjadi bahan baku industri barang kulit. Kekuatan tarik terbaik adalah dengan bahan penyamak mineral $10 \%\left(175,33 \mathrm{~kg} / \mathrm{cm}^{2}\right)$ dan kemuluran yang terbaik adalah dengan bahan penyamak sintetis $15 \%(41,00 \%)$. Sedangkan dengan bahan penyamak nabati tidak ada yang memenuhi persyaratan SNI.06-0253-1989 Kulit Glace Kambing, Mutu dan Cara Uji.
\end{abstract}

\begin{abstract}
The aim of the research was to make use of cow scrotum hides to be raw material in leathergood manufacturing. Forty five pieces of scrotum hides were tanned to crust leather using subsequently $6 \%, 8 \%$ and $10 \%$ mineral tanning agent; $15 \%, 20 \%$ and $25 \%$ vegetable tanning agent; $15 \%, 20 \%$ and $25 \%$ synthetic tanning agent. The physical test results indicated that scrotum cow hides were able to be made use as raw material in leathergood manufacturing. The best tensile strength value was achieved by those tanned with mineral tanning agent $10 \%\left(175,33 \mathrm{~kg} / \mathrm{cm}^{2}\right)$ and the best elongation at break was achieved by those tanned with synthetic tanning agent $15 \%(41,00 \%)$. Where as by using vegetable tanning agent, no single sample fulfiled the requirements of SNI. 06-0253-1989, Quality and Testing method for Glaced Kid Leather.
\end{abstract}

\section{PENDAHULUAN}

Kulit merupakan hasil sampingan pemotongan ternak yang mempunyai nilai cukup tinggi, sekitar 10-15\% dari harga ternak (Djojowidagdo, 1990). Bisa disamak menjadi berbagai macam jenis kulit jadi tergantung pada tujuan dan penggunaan produk akhirnya.

Pada saat ini perkembangan global perkulitan telah menunjukkan adanya kelangkaan akan penyediaan kulit mentah konvensional yaitu kulit mentah yang berasal dari hewan sapi, kerbau, domba dan kambing. Pengaruhnya banyak industri pengrajin kulit kekurangan bahan baku. Salah satu alternatif pilihan untuk mengatasi hal tersebut adalah pemanfaatan kulitkulit lainnya yang sebelumnya diabaikan, misalnya kulit skrotom.

Kulit skrotom adalah kulit berkantong yang ukuran dan bentuknya menyesuaikan dengan testis yang dikandungnya. Kulit skrotom tipis, lembut dan relatif kurang berambut

1) Balai Besar Penelitian dan Pengembangan Industri Barang Kulit, Karet dan Plastik Yogyakarta 
(Frandson, 1993). Kulit skrotom merupakan bagian dari kulit tubuh yang bentuknya berbeda yaitu menyerupai kantong yang terletak diantara kedua lipat paha. Dilihat dari bentuk tersebut kulit skrotom merupakan alternatif baru bagi industri penyamakan untuk bahan produksi tas atau dompet, karena dalam pembuatannya tanpa menggunakan jahitan sambungan dan hanya menggunakan aksesoris sedikit sudah bisa berbentuk tas atau dompet.

Semua kulit mentah mengandung kadar air $65 \%$, protein $33 \%$, mineral $0,5 \%$ dan kadar lemak alaminya $\pm 1,5 \%$. Pada protein tersebut didapatkan $\pm 98 \%$ kollagen, $1 \%$ elastin dan $1 \%$ keratin (epidermis dan bulu) (BASF, 1986). Keratin dihilangkan pada waktu proses liming (Oetojo, 1995). Kollagen disamak dengan menggunakan bahan penyamak (Wibowo, 1995). Selanjutnya Wibowo (1995) menjelaskan bahwa kulit yang sudah disamak merupakan produk yang diperoleh dengan cara menstabilkan protein yang ada pada kulit mentah melalui proses penyamakan. Bahan penyamak yang digunakan akan menyebabkan terjadinya ikatan silang ("cross linkage") rantai kollagen pada kulit. Mekanisme dan bentuk ikatan silang yang terjadi sangat ditentukan oleh bahan penyamak yang digunakan. Karena ikatan silang rantai kollagen yang terbentuk tersebut menyebabkan kulit mempunyai sifat khusus.

Keindahan barang jadi dari kulit sangat dipengaruhi oleh pengerjaannya, mudah tidaknya pengerjaannya sangat ditentukan oleh hasil penyamakannya (Lutfie, 1990). Tujuan dari penyamakan adalah untuk menghasilkan kulit tersamak yang sesuai dengan tujuan penggunaannya dan tuntutan mutu yang dikehendaki, misalnya tas, dompet (Wibowo, 1995). Metoda penyamakan dan bahan penyamak yang bisa digunakan ada beberapa macam, yang masing-masing akan menghasilkan kulitjadi yang berbeda-beda karena setiap bahan penyamak mempunyai sifat sendiri-sendiri. Semua kulit samak mempunyai sifat-sifat fisik dan kimiawi. Kekuatan tarik dan kemuluran adalah sangat dominan pada pemakaian kulit jadinya, seperti dikatakan oleh Pertiwi (1990) bahwa salah satu sifat fisis kulit boks yang penting adalah kekuatan tarik (Tensile Strength) dan kemuluran (elongation at break). Yang dimaksud dengan kekuatan tarik kulit adalah besarnya gaya maksimal yang diperlukan untuk menarik kulit sampai putus dan dinyatakan dalam $\mathrm{kg} / \mathrm{cm} 2$ atau Newton $/ \mathrm{cm} 2$, sedangkan yang dimaksud dengan kemuluran kulit adalah pertambahan panjang kulit pada saat ditarik sampai putus dibagi panjang semula dan dinyatakan dalam prosen.

\section{BAHAN DAN METODA PENELITIAN}

\section{Bahan}

1. Kulit skrotom sapi segar yang berasal dari Yogyakarta yang masih berbentuk kantong sebanyak 45 buah.

2. Bahan penyamak Chromosal B (mineral), valonea (nabati) dan Irgatan LV (sintetis) serta bahan pembantu penyamak.

\section{Metoda}

Perlakuan yang diberikan adalah penyamakan dengan berbagai jenis bahan penyamak serta level konsentrasi yang diberikan yaitu :

1. Dengan bahan penyamak mineral $=\mathrm{M}$

- $\mathrm{M} 1=6 \%$ Chromosal $\mathrm{B} \sim 1,5 \% \mathrm{Cr}_{2} \mathrm{O}_{3}$

- $\mathrm{M} 2=8 \%$ Chromosal $\mathrm{B} \sim 2,0 \% \mathrm{Cr}_{2} \mathrm{O}_{3}$ 
- $\mathrm{M} 3=10 \%$ Chromosal B $2,5 \% \mathrm{Cr}_{2} \mathrm{O}_{3}$

2. Dengan bahan penyamak Nabati $=\mathrm{N}$

- $\mathrm{N} 1=15 \%$ Valonea

- $\mathrm{N} 2=20 \%$ Valonea

- $\mathrm{N} 3=25 \%$ Valonea

3. Dengan bahan bahan penyamak sintetis $=\mathrm{S}$

- $\mathrm{S} 1=15 \%$ Irgatan LV

- $\mathrm{S} 2=20 \%$ Irgatan LV

- $\mathrm{S} 3=25 \%$ Irgatan LV

Setiap perlakuan menggunakan 5 buah skrotom sapi. Parameter yang diuji adalah kekuatan tarik dan kemuluran (daya regang). Berhubung kulit skrotom sapi tersebut keadaannya tipis seperti yang dinyatakan oleh Frandson (1993) maka tolok ukur yang digunakan adalah SNI.06-0253-1989 Mutu Dan Cara Uji Kulit Glace Kambing. Proses penyamakan kulit skrotom sapi tersebut dilaksanakan sesuai dengan tata cara proses yang ada pada laboratorium Proses Penyamakan Kulit di Balai Penelitian Industri Barang Kulit, BBKKP, Yogyakarta, dengan urutan sebagai berikut : liming, deliming, bating, degreasing, pickle, tanning, neutralization fatliquoring.

\section{HASIL DAN PEMBAHASAN}

\section{Hasil}

Tabel 1. Hasil pengujian kekuatan tarik dan kemuluran kulit kras Skrotom sapi dari berbagai variasi perlakuan.

\begin{tabular}{|cc|c|c|}
\hline Perlakuan & kekuatan tarik (kg/cm2) & Kemuluran (\%) \\
\hline \multirow{3}{*}{ Mineral } & M1 & 137,81 & $66,00 \%$ \\
& M2 & 160,27 & $84,00 \%$ \\
& M3 & 175,33 & $96,67 \%$ \\
Nabati & N1 & 60,95 & $57,33 \%$ \\
& N2 & 80,75 & $58,67 \%$ \\
& N3 & 89,53 & $59,33 \%$ \\
& S1 & 86,97 & $41,00 \%$ \\
Sintetis & S2 & 117,50 & $41,33 \%$ \\
& S3 & 124,00 & $44,00 \%$ \\
\hline
\end{tabular}

\section{Pembahasan}

1. Kekuatan Tarik

Setelah dianalisa secara statistik ternyata perbedaan jenis bahan penyamak yang diberikan berpengaruh sangat nyata $(P \leq 0,01)$ terhadap kekuatan tarik yang didapatkan, hal ini sesuai yang dikatakan oleh Jayusman (1990) bahwa sifat-sifat teknis dari kulit jadi sangat ditentukan oleh bahan penyamak yang diberikan.

Dilihat hasil uji pada Tabel 1. Ternyata yang disamak dengan bahan penyamak mineral (Chromosal B) kekuatan tariknya lebih tinggi bila dibandingkan dengan yang disamak dengan bahan penyamak nabati atau sintetis. Sesuai dengan sifat bahan penyamak krom bahwa kulit yang disamak dengan bahan penyamak krom akan didapatkan kulitjadi yang 
kuat dan lemas, hal ini mungkin karena terjadinya ikatan silang antar fiber kollagen kulit oleh bahan penyamak krom. Akibat dari ikatan tersebut maka struktur kulit menjadi kuat. Hal ini sesuai yang dikatakan oleh Oetojo (1994) bahwa dalam proses penyamakan kulit, krom akan berikatan dengan gugus karboksil kulit, sehingga kulit yang didapatkan mempunyai sifat kuat, lemas, tahan terhadap air mendidih dan penyerapan air kecil sekali apabila dibandingkan dengan kulit yang disamak dengan bahan penyamak lainnya. Hasil penelitian Lutfie (1994) juga meyebutkan bahwa kulit yang disamak dengan bahan penyamak krom baik secara tunggal maupun secara dikombinasikan dengan bahan penyamak lainnya akan menghasilkan kulit jadi yang lebih baik.

Dari berbagai variasi jumlah bahan penyamak yang diberikan, ternyata semuanya menunjukkan hasil yang berpengaruh sangat nyata $(\mathrm{P} \leq 0,01)$ terhadap kekuatan tarik yang dihasilkan. Bila dibandingkan dengan tolok ukur yang digunakan SNI.06-02531989 Mutu dan Cara Uji Kulit Glace Kambing pada parameter kekuatan tariknya (minimal $150 \mathrm{~kg} / \mathrm{cm} 2$ ) ternyata yang memenuhi persyaratan yang disamak dengan 8 dan $10 \%$ Chromosal B $(160,27 \mathrm{~kg} / \mathrm{cm} 2$ dan $175 \mathrm{~kg} / \mathrm{cm} 2)$, sedangkan yang disamak dengan $6 \%$ Chromosal B tidak memenuhi persyaratan yaitu hanya $137,81 \mathrm{~kg} / \mathrm{cm} 2$, ini mungkin dikarenakan penyamakannya belum sempurna. Graves (1986) menyatakan bahwa kulit bisa tersamak masak apabila jumlah $\mathrm{Cr}_{2} \mathrm{O}_{3}$ yang diberikan minimal $2 \%$.

Pada Tabel 1. Juga terlihat bahwa makin bertambah jumlah Chromosal B yang diberikan makin tinggi kekuatan tarik yang dihasilkan. Hal ini mungkin dengan bertambahnya Chromosal $\mathrm{B}$ yang diberikan maka kadar $\mathrm{Cr}_{2} \mathrm{O}_{3}$ nya juga bertambah sehingga tingkat kemasakan kulit juga lebih sempurna karena jumlah $\mathrm{Cr}_{2} \mathrm{O}_{3}$ yang terserap dan protein yang tersamak tentunya lebih banyak. Hal ini sesuai yang dikatakan oleh Oetojo (1994) bahwa makin bertambah garam krom basa yang diberikan maka makin meningkat kadar $\mathrm{Cr}_{2} \mathrm{O}_{3}$ pada kulit yang dihasilkan.

Dengan sempurnanya tingkat kemasakannya maka ikatan silang rantai kollagen yang terjadi pada kulit tentunya juga lebih sempurna, sehingga ini menghasilkan kekuatan tarik kulit lebih tinggi atau lebih kuat. Hal ini sesuai dengan pendapat Wibowo (1995) bahwa ikatan silang rantai kollagen yang terbentuk oleh bahan penyamak $\mathrm{Cr}_{2} \mathrm{O}_{3}$ menyebabkan kulit mempunyai sifat khusus yaitu kulit tidak mengembang atau membengkak jika terkena air, tidak mengkerut jika kering, lebih stabil terhadap suhu tinggi serta kulit menjadi elastis dan fleksibel.

Berbeda dengan kulit yang disamak dengan bahan penyamak nabati dan sintetis, kekuatan tariknya lebih rendah bila dibandingan dengan kulit yang disamak dengan bahan penyamak mineral. Hal ini mungkin dikarenakan oleh sifat kulit yang disamak dengan bahan penyamak nabati atau sintetis adalah mudah menyerap air, dan ini berakibat serabut kulit menjadi melemah sehingga kekuatan tarik kulit menjadi menurun, seperti yang dikatakan oleh Raharjo (1990) bahwa berdasarkan karakteristik kimiawinya berbagai bahan penyamak menghasilkan kulit samak dengan kualitas yang berbeda serta dengan masing-masing metoda perlakuannya memiliki kelebihan dan kekuarangannya sendiri-sendiri.

2. Kemuluran

Seperti halnya dengan kekuatan tarik, ternyata jenis bahan penyamak mineral, nabati dan sintetis berpengaruh sangat nyata $(\mathrm{P} \leq 0,01)$ terhadap kemuluran kulit kras skrotom sapi.

Majalah Barang Kulit, Karet dan Plastik, Vol. XV, No. 2, Tahun 1999 
Rataan nilai kemuluran tertinggi terdapat pada kulit yang disamak dengan bahan penyamak mineral (10\% Chromosal B) yaitu 96,67\%. Sedangkan yang terendah didapatkan pada kulit yang disamak dengan bahan penyamak sintetis ( $15 \%$ Irgatan LV) yaitu $41,00 \%$. Bila dibandingkan dengan tolok ukur yang digunakan SNI.06-0253-1989 Mutu dan Cara Uji Kulit Glace Kambing pada parameter kemuluran (maksimal 50\%) maka yang memenuhi persyaratan fisis adalah yang disamak oleh bahan penyamak Irgatan LV baik yang $15 \% ; 20 \%$ dan $25 \%$ yaitu $41,00 \% ; 41,33 \%$ dan $44 \%$.

Kulit yang disamak dengan bahan penyamak sintetis, menjadi lebih padat, makin tinggi bahan penyamaknya makin padat kulit yang dihasilkan. Namun kemuluran yang dihasilkan tidak berbeda nyata. Kemungikinan pemakaian variasi jumlah pemakaian belum menampakkan perbedaan yang nyata, sehingga kemuluran yang terjadi tidak berbeda nyata yaitu $41,00 \% ; 41,33 \%$ dan $44, \%$.

Sedangkan yang disamak dengan bahan penyamak nabati hasil ujinya adalah $57,33 \%$; $58,67 \%$ dan 59,33\%. Berdasarkan dengan tolok ukur hasil uji ini tidak memenuhi persyaratan yaitu $50 \%$. Namun hal ini bisa dikurangi dengan cara memperkecil jumlah minyak yang diberikan. Kelebihan mulur tersebut juga bisa disebabkan oleh sifat dasar bahan penyamak nabati yang digunakan, yaitu lebih lemas dibandingkan dengan yang dari sintetis, kelemasan tersebut juga berpengaruh terhadap kemuluran yang dihasilkan. Penyamakan dengan bahan penyamak mineral (Chromosal B) memberikan kemuluran yang tertinggi yaitu $96,67 \%$. Makin tinggi bahan penyamak yang digunakan maka makin tinggi pula kemuluran yang dihasilkan. Hal ini disebabkan karena kulit tersamak oleh pemberian bahan penyamak mineral (Chromosal B), ikatan silang antar fiber kollagen lebih senpurna. Ikatan silang yang sempurna mengakibatkan kekosongan antar serat. Akibat dari kekosongan ini, maka mudah dimasuki oleh minyak yang diberikan pada waktu proses peminyakan (fatliquoring) berlangsung. Bahan peminyakan yang diberikan dapat menembus dan berpenetrasi ke dalam ikatan-ikatan serat, serta antara ikatan serat, sehingga menyebabkan serat-serat menjadi stabil dan mempunyai sifat elastis yang sangat baik. Hal ini sesuai yang diungkapkan oleh Jayusman (1990) bahwa tujuan peminyakan (fatliquoring) adalah untuk memberikan pelicin pada jaringan kulit, sehingga serat-seratnya lebih bebas digerakkan, dengan demikian kulit menjadi lemas dan lebih awet.

Dilihat dari Tabel 1 yaitu bila kekuatan tariknya tinggi maka kemulurannya juga tinggi dan bila kekuatan tariknya rendah maka kemulurannya juga rendah. Ini sesuai yang dikatakan Pertiwi (1990) bahwa antara kekuatan tarik dengan kemuluran kulit mempunyai hubungan walaupun sangat lemah dan bersifat searah yaitu setiap kenaikan atau penurunan nilai kekuatan tarik akan terjadi bersama-sama dengan kenaikan atau penurunan nilai kemuluran kulitnya. Dengan lain perkataan semakin tinggi kekuatan tariknya, semakin tinggi pula kemulurannya dan sebaliknya.

Bila dilihat hasil uji pada Tabel 1 tersebut di atas maka langkah terbaik yang dapat diambil untuk penyamakan kulit skrotom sapi adalah menggabungkan bahan penyamak tersebut, sehingga bisa didapatkan kulit jadi yang lemas tetapi padat, kuat, montok dan lemas, seperti hasil penelitian Lutfie (1996) terbukti bahwa dengan menggunakan bahan penyamak lebih dari satu untuk menyamak kulit maka akan didapatkan sifat-sifat yang dipunyai oleh bahan penyamak tersebut yaitu didapatkan kulit jadi yang lemas, kekuatan tarik dan kemulurannya lebih baik bila dibandingkan dengan disamak tunggal bahan penyamak. 


\section{KESIMPULAN}

1. Kulit skrotom sapi bisa dimanfaatkan sebagai bahan baku industri kulit.

2. Kulit skrotom sapi yang disamak dengan bahan penyamak mineral mempunyai kekuatar tarik yang tinggi yaitu $175,33 \mathrm{~kg} / \mathrm{cm} 2(10 \%$ Chromosal B), dan disamak dengan bahar penyamak sintetis mempunyai kemuluran yang rendah yaitu $41,00 \%$ (15\% Irgatan LV)

3. Sedangkan dengan bahan penyamak nabati tidak ada yang memenuhi persyaratan SNI.06. 0253-1989 Kulit Glace Kambing, Mutu dan Cara Uji.

\section{DAFTAR PUSTAKA}

BASF, 1986. Pocket Book for The Leather Technologies. BASF. Aktiengellscaft. D-6700 Ludwigshafen B.352 e.

SNI.06-0253-1989. Mutu dan Cara Uji Kulit Glace Kambing. Dewan Starndardisas Nasional.

Djowidagdo S, 1990. Penyakit Kulit Pada Ternak Yang Dapat Menurunkan Mutu Kuli Samak. Proceedings Seminar Sehari HAKTKI. Yogyakarta.

Frandson, R.D., 1993. Anatomi dan Fisiologi Ternak. Edisi Ke IV. Gadjah Mada University Press PO BOX 14 Bulak sumur. Yogyakarta.

Graves, R.G., 1986. Leather Technology. New College, Northampthon. NN.37.UI.UK. England.

Jayusman, 1990. Pengetahuan Bahan. DP/BPDI/BBKL/01/91. Balai Besar Penelitian dan Pengembangan Industri Barang Kulit, Karet dan Plastik. Yogyakarta.

Lutfie M.; Meiyanti; Rahayu E.; Rachmi R., 1994. Teknologi Penyamakan Kulit Ikan Kakap. Bulletin Sains dan Teknologi Kulit. HAKTKI. Yogyakarta.

Lutfie M; Widhiati; Suryaningsih P.E.; Kasmudjiastuti E.; Rahayu E., 1996. Pemanfaatan Larutan Limbah Krom Sebagai Bahan Pratanning Pada Pembuatan Kulit Lapis Samak Kombinasi (Krom + Nabati) Dari Kulit Kambing. Bulletin Sains dan Teknologi Kulit. HAKTKI. Yogyakarta.

Oetojo B.; Lutfie M.; Widari; Widhiati; Basalamah H., 1995. Penelitian Proses Pengapuran - Pembuangan Bulu Menurut Metode Herfeld. Majalah Barang Kulit, Karet dan Plastik. BBKKP. Yogyakarta.

Oetojo B., 1994. Penelitian Penggunaan $\mathrm{Cr}_{2} \mathrm{O}_{3}$ Minimum Untuk Menyamak Masak Kulit Kambing. Bulletin Sains dan Teknologi Kulit. HAKTKI. Yogyakarta.

Pertiwi S.R. dan Widodo, 1990. Hubungan Antara Kekuatan Tarik (Tensile Strength) Dengan Kemuluran (Elongation At Break) Kulit Boks. Proceedings Seminar Sehari HAKTKI. di Yogyakarta.

Raharjo, Y.C, A. Budiman, K. Suradi, T. Sartika dan B. Oetojo, 1990. Pengaruh Berbagai Jenis Bahan Penyamak Dalam Penyamakan Kulit Bulu Terhadap Kualitas Kulit Bulu Samak Kelinci Rex. Proceedings Seminar Sehari HAKTKI. di Yogyakarta.

Wibowo dan Susanto H., 1995. Sumber Daya dan Pemanfaatan Hiu. PT. Penebar Swadaya. Jln. Gunung Sahari III/7. Jakarta. 